\title{
A Revision of Kola Babarinde's Stance on Value Statements In Education
}

\author{
Ikeoluwapo B. Baruwa \\ Department of Early Childhood and Educational Foundations, University of Ibadan, Nigeria. \\ ikeoluwapobaruwa@gmail.com
}

\begin{abstract}
The place of value statements in education cannot be undermined and should consequently not be overemphasized. Value statements have been characterized to be part of most educational discussions and writings, however, its centrality should not be hindered (rather worked on) as conceived and supported by some philosophers, as against the logical positivists or empiricists who considered it to be a mere expression of thoughts. As the popular saying is, when the purpose of a thing is not known, abuse becomes inevitable; this paper seeks a revision of Kola Babarinde's stance on value statements in education, and further emphasizes the position value plays in the contemporary schools.
\end{abstract}

\section{Keywords:}

Kola babarinde, value statement, education,

\section{INTRODUCTION}

This paper is interested in seeking a conceptual analysis of what Babarinde presented in his paper titled, 'the relevance and limitations of value statements in education'. As highlighted by Babarinde, the concept and stance of value statements have been argued overtime to that with a lack of logical stringency. This, in turn, has been further argued to be the genesis of failure of schools in particular and that of the institution of education in general. However, as earlier posited, this paper seeks to make a critique of Babarinde's position; whilst this paper agrees with some of the arguments in the original work, this paper further sets its departure and states reasons why the stance of value is of major concern to the contemporary pedagogy. In this study, the concept of value statements in education and the place of value in schooling (that is, can the schools teach value?) shall be of critical concern.

\section{SEEKING A REVISION}

In response to the paper, 'relevance and limitations of value statements in education', this paper agrees with the author in his analysis of what value statements entails. In his work, value statements were broken down into constituents and later formed as a whole in the body of his examination and analysis. He started with a brief introduction of how value statements are expressed and how they make up our everyday life. For him, human living, depicted by conversations or relationships are guided by values or value statements. In other words, the expressions of values or value statements cannot be separated, as it has become part of our daily living, even when we 
do not take direct cognizance of these expressions in our manner of conversations. Hence, it becomes more permeating and pervading in education for sake of a field of human endeavor that concerns itself with the lives of all beings, and therefore, confers on the prerogative often taken to be a 'legislate' or to offer 'expert opinion' on educational issues. To corroborate the emphasis of the author, Babarinde established that, 'one basic activity in human life is making choices. Thus, whenever we choose, we confer values on the object of choice. Value plays an important role in human life, especially in making choices as conceived, and this makes it important why value should be taught in schools (emphasis is mine). One might ask, what then are value statements? Or, what is the value that makes it a statement? Value statements can be seen to have been derived from the popular branch of philosophy, axiology, which means the nature of a value or what constitutes theories of value.

Here, in axiology, there are subdivisions of both ethics (the study of what is right or wrong, ethical or unethical, acceptable or unacceptable, good or bad, which guides human conduct) and aesthetics (the study or nature of beauty). Hence, adjectives/words like wrong, bad, good, beautiful, moral, and the like are contained in value statements, and as earlier established, can be seen under the branch of axiology (nature of value). However, there is no truth claim in value statements (and this is one of the reasons why the logical positivists or empiricists considered it as mere verbal ejaculation). Taking this for example as cited by Babarinde: In a statement such as green is the best color for school uniform, it will be meaningless to say true or false except to signify or withhold support. He submitted that the nature that statements of value take, can be likened to that of prescriptions and which in turn has been described as elliptical statements - badly stated or incomplete statements.

Going by the analysis of the paper, he examined value statements with other related concepts such as analytical statements (All men are mortal, a bachelor is an unmarried male, empirical statements (Mr. Jumbo is $5 \mathrm{~m}$ tall, the temperature inside this auditorium is $32^{\circ}$ centigrade). In the aforementioned examples, he positioned that empirical statements are truth claims because they refer to a state-of-affairs which are verifiable on their own. On the other hand, analytical statements are considered a priori, which are statements necessarily to be true. That is, true in themselves. In his submissions, he suggested that the best that can be done is to render value statements into propositions or statements of implication, which in turn can bring about truth claim, if not to be taken as mere verbal ejaculation as described by philosophers of logical positivism. Thus, for instance, one can consider the statement 'green is a better color for school uniform' to imply a stipulation or prescription to the effect that 'green color is to be preferred for school uniform'. In this case, as it is common with expressions of taste, it can be neither true nor false; rather, a wise comment should be: 'it all depends'. And if this is the case, it means the 
kind of treatment given to prescriptions may be feasible when dealing with value statements. And this treatment is the reduction of value statements to proposition or statement of implication.

For Babarinde, the use of value statements must be reduced to the minimal level, especially by educators who unwittingly employ it in all areas of education. He further added that value statements are plagued with conceptual difficulties, therefore, philosophers in time past have rendered it questionable with reasoned arguments.

\section{CAN SCHOOL TEACH VALUE?}

What is the value that the school should teach or not teach? Let me reiterate by conceptualizing value as one that regulates and guides human behavior and action in our day-to-day life.

The concepts of value and norm are sometimes misconstrued and used interchangeably. For emphasis or clarification, while norm can be used for a relatively specific pattern of expected behavior, and which is mostly obligatory to the users, the value can be considered a matter of one's choice. Considering, for instance, the use of 'discipline', it could be a value or a norm depending on the context of usage or understanding. Discipline could be adopted in every sphere of human engagement or activity, but it is to be reminded that, not everyone can follow it. Like it's popularly said, you can force a horse to the river but you cannot force him or her to drink from the river. Thus, discipline in this context can only become a value when there is an internalization by the party or user involved. And for the norm on the other hand, once there is internalization as earlier said, there is a tendency for such value to become a norm in making preferences and judgment for one's choice or need. Thus, one's choice makes value subjective, and as it exists or conforms to the world of reality, values become present or embedded in every action. It is of imperative therefore to bear in mind that, values become seen in every word an individual selects and speaks, or what one wears; ways in which one interacts with his or her fellow beings, in every perception and interpretation of others, in every reaction and other human engagements. In situ, values are formed on the ground of one's interests, desires, choices, and preferences.

To the question raised in Babarinde's paper, can school teach value? Or why should school teach value? Babarinde could have over assumed in a few of his arguments by saying that, 'to say that schools should teach values would be the same as asserting that the school should do what is necessary to fulfill its assigned tasks. Also, saying that the task of the school is to teach values, therefore, directing the school to teach it would be a contradiction is an assumption. Like the popular saying, if the purpose of a thing is not known, abuse is inevitable. In the same vein, the task of teaching value is not only subsumed in the school, but we also have family, society, and other societies at large. Therefore, the conclusion seems wrong to have been arrived at. In the same vein, Babarinde argued that 'if the basic activity of the school such as literacy has become so difficult to achieve, how much more a highly complex 
trait such as value which is as elusive as much as it is ambiguous? Babarinde seems to be wrong to have concluded that the task of the school in the former is basic (literacy) and the other is complex (value). Questions to be raised here is: does one teach literacy without value? Do these tasks (literacy and value) run simultaneously or subsequently?

Examining these two ideas, it could be said that Babarinde committed reductio ad absurdum (reduction to the absurd) in his analysis. For instance, arguing that the school should not teach value because it belongs to the school and arguing that value has become elusive and ambiguous is contradictory on its own. Should we assume the responsibility of teaching value lies only in the school? Or, from the arguments raised by him, when something becomes complex, is it not necessary to be taught or developed that one might know its importance?

As a point of reinvigorating the separated links in these ideas, it would have been said that, though the responsibility of teaching value lies not only in the school, therefore, the teaching of such would be deemed necessary.

\section{CAN SCHOOL TEACH VALUE?}

Education without values, as useful as it is, seems rather make the man a cleverer devil. Thus, the whole endeavor of education is practically linked with the development of values in the receiver.

In Plato's account on the republic, the philosopher-kings education aims beyond the attainment of the four virtues and includes the greatest and most beneficial study: that of "the good'. Similarly, Awolowo recognized education as a systematic course of instruction involving giving intellectual and moral training to persons, bringing up the young, helping the young to develop, to lead out the best in him, and to evolve an integral personality . Bamisaiye in analyzing the concept of education viewed it as a concept which must affect the social behavior of the person being educated and in addition to this, education is necessarily a process of inculcating values to equip the learner to live a life $-a$ kind of life that is satisfying to the individual by the cherished values and ideals of the society

Considering the definitions above, can school teach value? Or can one receive an education without value? Or do one go to school without receiving value directly or indirectly? According to J.A. Akinpelu, an educated man is such a man who combines expertise in some specific economic skills with the soundness of character and wisdom in judgment. He added that an educated man is a person who is wise, shrewd in judgment excellent in character. It should be noted that the mark of an educated person according to Plato in The Republic, is the willingness to use one's knowledge and skills to solve the problems of society. Do we now say the schools should teach value or not if it constitutes the fulcrum of what makes us an educated person?

Notwithstanding, if the question is asked, can school teach value? If the answer to the question is no, it could be asked that, why is it that most tertiary institutions emphasize the character and learning of 
their students? Why do we have the University of Ibadan emphasize on the good character and sound judgment of her students? And, if the answer to the question is yes, one could ask how did the nation get to this state of poor social values and rampant unethical practices that pervade the democratic situation in Nigerian society? The responsibility of the school is to teach the value and one should not assume that value is of the school and therefore not necessarily needed to be taught. Poor social values emerged as a result of many factors and that is why there is a dire need to address the issue of value in schools. The school must make a conscious effort at leading out such great value potentials in man and as John Locke rightly said, the aims of education should be to create a virtuous man and not only a scholar .

\section{THEN, WHY SHOULD SCHOOLS TEACH VALUES?}

Value introduces students to faulty rationalization and helps them make ethical decisions, without resulting in unethical judgments, even amidst external pressures. Thus, ethical discussions can shape the learners to better understand the perils of making faulty rationalization and better enrich them to handle external pressures in their pursuit.

Value creates a mature personality, that learners imbibe positive traits like tolerance, empathy, assertiveness, and leads to a healthy lifestyle.

In the same manner, it exposes the student to opposing viewpoints or contrasting ethical opinions, and also provide a platform to better understand the reasons behind every difference or variation.

Adoption of value can help sustain the society from various social problems such as violence, dishonesty, corruption, kidnapping, rape, ritual killings, and other social problems today. As duly considered, the teaching of moral values in schools would limit the aforementioned problems. At the societal level, education for values must aim at promoting social cohesion and national integration for transforming societies, nations and in creating a better world

Good articles on ethics are effectively specialtopic exemplars of advanced critical thinking skills. Students who study such first-rate reasoning in the classroom stand a better chance of being able to engage in solid ethical reasoning in the workplace.

The development of ethical decision-making skills allows students to leverage a competitive advantage into a great job and prepares them to become future business leaders.

Gardelli et al once presented three arguments supporting why ethics should be taught in schools. For them, they identified the socialization argument, the quality of life argument, and the tool argument. For Gardelli et al, the socialization argument emphasizes the need to help students become good and great citizens, and to achieve this feat, they argued that ethics becomes crucial in the teachinglearning process. Second to that is the quality of life argument, which argues that schools should foster in learners to become persons of moral character. Lastly, the tool argument is of the concern that, 
when ethics are considered, the results of learners in other subjects would be better improved1.

Bringing to the fore, Babarinde would be wrong to have concluded that schools should teach critical thinking without an emphasis on the corroboration of both critical thinking and value in schools. The questions here are: Do we teach or develop critical thinking in learners? What is critical thinking without value? Do we teach critical thinking or skills? Let me attempt the questions one after the other. The word, 'Critical', derived from the Greek word Kritikos, which means 'to judge', arose out of the way analysis and Socratic argument comprised thinking at that time2 and then the word kritikos passed to Latin as 'Criticus' that is the type of spreading to world languages from it3. Critical thinking can be described as an ability beyond memorization. In this, when learners think critically, they are encouraged to think for themselves; to question hypotheses, to analyze, and to synthesize the events.

Questioning as the cornerstone of critical thinking is the source of knowledge formation and the guide or framework for all learning. A critical thinker here goes one step further by developing new hypotheses and test them against the facts obtained. Do we then teach critical thinking or

${ }^{1}$ Gardelli, et al. 2014. Why Philosophical Ethics in School: Implications for Education in technology and General in Ethics and Education, Vol. 9, No:1, pp. 16-28

2 Karakoc, M. 2016. The Significance of Critical Thinking Ability in terms of Education. International Journal of Humanities and Social Science. Vol. 6, No. 7

3 Hançerlioğlu, O. 1996. Felsefe Sözlüğü. İstanbul: Remzi Ktabevi:31. develop in learners the ability to think critically? In the author's submission, critical thinking can only be developed in learners, therefore, it would be wrong to say we teach critical thinking as if we teach or pass the knowledge of ' $A B C$ ' to the learners or educands. However, for as much as critical thinking can be developed, it should be searched and analyzed concerning its different dimensions.

To the question of value and critical thinking running simultaneously, values are developed not by forcing people to memorize words but by the use of reason, and like John Locke stated, to follow reason is to live a life of self-denial; the ability to resist the satisfaction of our desires and follow where reason leads instead4. In the same vein, value, as posited by Socrates, is a higher reality that is responsible for our capacity to reason as well as our very 'existence and being'5. Therefore, the concepts of critical thinking and value cannot be separated in the teaching-learning process.

\section{SUMMARY}

Value statements, as emphasized from the inception of this paper heretofore, have been discovered with a lack of logical stringency, as overly employed by educators, and this, in turn, has contributed to the failure of schools in one way or the other. As posited by Kola Babarinde, value statements must be rendered into propositions especially in educational writings and discourses to

4 Akinpelu, J.A. 1981. An Introduction to Philosophy of Education.

${ }^{5}$ Akinpelu, J.A. Ibid 
save any misconceptions that may arise. Similarly, as argued by the author, the interest or focus of the school lies in the development of morally sound learners, and that is why most if not all societies, would expect an educated man or an individual who has undergone a formal education to possess attributes like honesty, assertiveness, meekness, tolerance, humility amongst others.

\section{Acknowledgment}

Special thanks to my teacher and senior colleague (as I fondly call him), in the person of Professor Kola Babarinde (of the Department of Early Childhood and Educational Foundations, University of Ibadan) for this privilege.

\section{REFERENCES}

Akinpelu, J. A. (1981). An introduction to the philosophy of education. London: Macmillian Education Ltd

Awolowo, 0. (1981). Voice of wisdom. Akure: Fagbamigbe Publishers

Babarinde, K. (1995). Relevance and limitations of value statements in education. Ilorin Journal of Education. Vol. 15

Bamisiaye. R. (1989). A practical approach to the philosophy of education. Ibadan AMD Publishers

Daya, P. Et al. Education for values in schools: A Framework. Retrieved on 20th March 2019

Gardelli, et al. (2014). Why philosophical ethics in school: implications for education in technology and in general in ethics and education, Vol. 9, No: 1

Hançerlioğlu, O. (1996). Felsefe Sözlüğü. İstanbul: Remzi Ktabevi:31

Karakoc, M. (2016). The significance of critical thinking ability in terms of education. International Journal of Humanities and Social Science. Vol. 6, No. 7

Lewis, C. S. The importance of teaching values in education. Retrieved on 24th March 2019

Locke, J. (1996). Some thought concerning education and of the conduct of the understanding. Edited by Natan Tarvov and Ruth W, Grant. Indianapolis,IN:Hacket.

McGregor, D. (2007). Developing thinking, developing learning. Open University Press

Plato. (2000). The republic, University Press: Cambridge.

Walsh, D., \& Paul R. (1988). The goal of critical thinking: From educational ideal to educational reality. Washington, D. C: American Federation of Teachers 